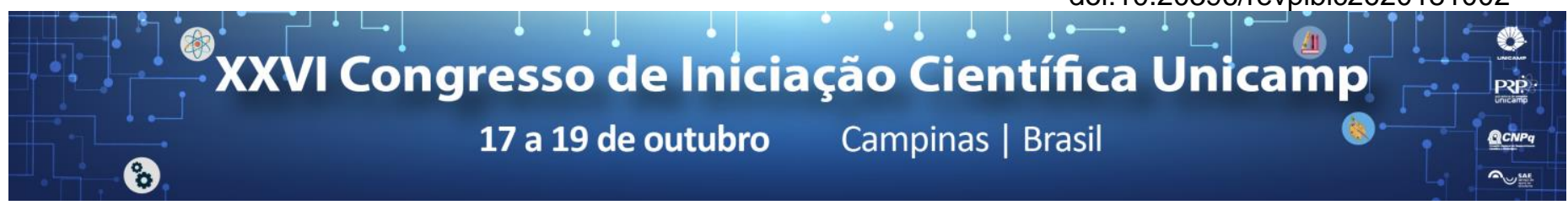

\title{
Empreendedorismo Universitário, a Nova Economia e Colaboração: Um estudo de caso sobre uma "start up" de cultura na Universidade Estadual de Campinas
}

\author{
Marília P. A. Veríssimo*, Miguel J. Bacic
}

\begin{abstract}
Resumo
Esse projeto visa estudar como o empreendedorismo nas universidades tem sido afetado pela nova economia,que tem se desenvolvido na última década que visa a colaboração entre players e usuários, sobretudo em serviços oferecidos online. Partiu-se da hipótese de que a economia colaborativa afetou positivamente o ecossistema empreendedor universitário, ao viabilizar realizações coletivas que podem ser implementadas a partir de novos conceitos de produtos ou serviços com o uso da tecnologia de informação e baixo custo de investimento inicial, resultando em uma flexibilização das relações de trabalho e o aumento do impacto social e econômico. Como metodologia foram adotados, tanto uma revisão bibliográfica, como um estudo de caso sobre uma startup de divulgação de eventos culturais criada na Universidade Estadual de Campinas, numa parceria de diversos campos da universidade. A importância desse trabalho para a comunidade acadêmica se dá ao propor uma discussão sobre o papel da universidade como potencial formadora de novos negócios, e sua capacidade de inovação ao analisar a economia colaborativa como um panorama permanente com potencial para transformar o sistema capitalista e as relações econômicas, sociais e culturais que o perpassam.
\end{abstract}

\section{Palavras-chave:}

Empreendedorismo Universitário, Economia Colaborativa, Start-ups

\section{Introdução}

Esse trabalho busca expor a seguinte questão: como o empreendedorismo universitário - alunos que se utilizam do ambiente acadêmico para gerar e fomentar novos negócios muitas vezes em co-criação com outros alunos e entidades - tem sido proporcionado a partir do panorama da Economia Colaborativa. Partiu -se da hipótese de que esta afeta positivamente 0 empreendedorismo, uma vez que viabiliza projetos coletivos que podem ser facilmente implementados graças à conceitos novos de produtos ou serviços com o uso de tecnologia de informação e baixo custo de investimento inicial. Para corroborar tal hipótese, apresentou-se o caso do Curtir sua Cidade, uma plataforma gratuita e colaborativa de divulgação de eventos na região de Campinas criada entre os anos de 2015 e 2017 graças à colaboração de atores do ecossistema da Unicamp: a fundadora, diretora da Liga Empreendedora, alunos da ciência da computação e professores dos Institutos de Artes e de Economia.

\section{Resultados e Discussão}

Partindo de uma abordagem de incentivo à pesquisa com uma intenção de integração ao processo produtivo, a Unicamp adota uma postura de combinação entre o conhecimento técnico-científico e o mercado, criando mecanismos que apoiam ações empreendedoras. Em levantamento feito em 2016 pela Inova em parceria com a Diretoria Acadêmica (DAC), foi registrado uma taxa de empreendedorismo de quase $8 \%$ entre ex-alunos da universidade, o que correspondeu a cerca de 6 mil pessoas que seguiram a carreira empreendedora e abriram novos negócios após se formarem na Unicamp.

\section{Conclusões}

A proposta de valor do caso apresentado pode oferecer uma perspectiva real sobre o novo panorama econômico que tem se instalado ao longo dos últimos dez anos. A transição de um modelo econômico baseado em produtos para um novo, guiado em serviços, sobretudo online, tem ocorrido desde a década de 1990. No entanto, nos últimos anos, o aumento das ferramentas de interação online e da criação de redes sociais proporcionou um ambiente positivo para a reintrodução de um modelo de cooperação e compartilhamento entre usuários que existia desde o início das civilizações; porém mais evoluído. Nesse sentido, as universidades que adotam uma postura de apoio ao empreendedorismo, como é o caso da Unicamp, contribuem para a cadeia de valor produtivo da economia colaborativa, uma vez que incentivam a multidisciplinaridade, sejam por meio de cursos sobre inovação e novos negócios oferecidos para todos os alunos do campus, ou por competições de empreendedorismo (Desafio Unicamp), mas também a colaboração entre entidades institucionais (como a Inova e a Incamp) e os alunos/corpo docente para fomentar iniciativas inovadoras em tecnologia e informação e gerar novos negócios que impactarão tanto o ecossistema acadêmico como também o global.

\section{Agradecimentos}

Ao Professor Miguel Juan Bacic e meu pai, Mário Sérgio Veríssimo. Aos meus colegas da Liga Empreendedora. Ao CNPQ pela concessão da bolsa de pesquisa.

VERÍSSIMO. Marília; BACIC, Miguel. Empreendedorismo Universitário: Um Estudo De Caso Sobre Uma "Start Up" De Cultura Na Universidade Estadual De Campinas (Brasil). In: VI Workshop 'Función Empresarial y Creación de Empresas' - ACEDE, y XI Workshop Investigación Basada en GEM. 2017. Albacete, Espanha.

INGLEZ, M. N. Z; ANDRADE, N. D; ULTREMARE, F; MORI, M. O Perfil Empreendedor Dos Egressos Da Unicamp. 26 $6^{\text {a }}$ Conferência Anprotec. 17 a 20 de Outubro de 2016.

BRASIL JUNIOR. Índice de Universidades Empreendedoras. São Paulo. 2017. Disponível em: http://brasiljunior.rds.land/indice2017 